\title{
STUDI HADIS - HADIS TENTANG SHALAT JENAZAH
}

\author{
Fredika Ramadanil \\ Dosen Fakultas Ushuludddin dan Studi Agama \\ UIN Imam Bonjol Padang
}

\begin{abstract}
Abstrak
Merupakan sebuah kewajiban bagi setiap muslim untuk menyelenggarakan jenazah saudaranya jika meninggal dunia. Salah satu dari kewajiban tersebut adalah menshalatkan jenazah. Adanya berbagai macam sikap dan pengamalan kaum muslimin dalam menshalatkan jenazah seperti dalam menentukan siapa orang yang berhak untuk menjadi imam dalam shalat jenazah, dan beleh atau tidaknya menshalatkan jenazah pelaku maksiat seperti jenazah pelaku zina dan jenazah koruptor yang telah menimbulkan polemik dan perdebatan di kalangan ahli ilmu sekarang ini. berbagai macam sikap kaum muslimin tersebut di atas juga didasarkan pada hadishadis Rasulullah SAW yang mana kualitasnya ada yang shahih, hasan dan dhaif. Oleh karena itu, penelitian ini akan membahas bagaimana kehujjahan dan pemahaman hadis tentang shalat jenazah yang lebih terfokus kepada hadis-hadis tentang siapa orang yang berhak mengimami shalat jenazah dan hadis tentang Rasul tidak menshalatkan jenazah pelaku maksiat seperti jenazah pelaku zina dan jenazah koruptor.
\end{abstract}

Key words: Shalat Jenazah, kehujjahan, pelaku zina, koruptor

\section{PENDAHULUAN}

Kematian merupakan sunnatullah yang pasti akan mendatangi manusia bila waktunya telah tiba, bahkan kematian itu tidak bisa dimajukan dan dimundurkan walaupun hanya sedetik saja. Allah SWT berfirman:

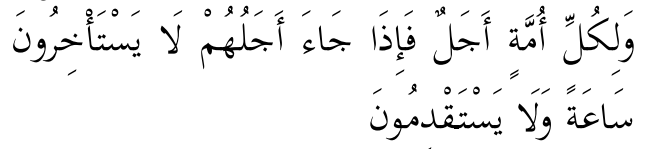

Artinya: tiap-tiap umat mempunyai batas waktu, Maka apabila telah datang waktunya mereka tidak dapat mengundurkannya barang sesaatpun dan tidak dapat (pula) memajukannya. (Q.S. al-A'raf ayat 34)

Dalam ketentuan hukum Islam, jika seorang muslim meninggal dunia maka wajib bagi orang muslim yang masih hidup untuk menyelenggarakan jenazah saudaranya yang meninggal itu. Kewajiban tersebut adalah memandikan jenazah temasuk di dalamnya membersihkan segala kotorannya, selanjutnya mengkafani jenazah dengan kain secukupnya dan disunnahkan kafan terbaik yaitu putih, bersih, tebal, rapat dan sederhana. Setelah jenazah selesai dikafani maka kewajiban selanjutnya adalah mensholatkan jenazah dan menguburkannya.

Ulama telah sepakat bahwa hukum shalat jenazah adalah fardhu kifayah. Rasul SAW menganjurkan kepada umat Beliau untuk menshalatkan jenazah kaum muslimin 
yang meninggal dunia, hal itu karena mayat akan mendapatkan syafaat dari orang muslim yang mensholatkannya selama keduanya tidak melakukan kesyirikan kepada Allah Swt.. Hal ini menunjukkan betapa pentingnya shalat jenazah terhadap si mayat sehingga Rasul Saw. selalu menyempatkan diri untuk shalat jenazah meskipun jenazah tersebut telah dikebumikan sekalipun.

Dalam melaksanakan shalat jenazah, ada beberapa hal yang harus diperhatikan antara lain seperti orang yang berhak mengimami shalat jenazah dan shalat jenazah atas pelaku maksiat dalam hal ini terfokus pada jenazah pelaku zina dan koruptor.

Dalam salah satu hadis disebutkan bahwa orang yang berhak mengimami jenazah adalah keluarga si mayat. hal ini berdasarkan riwayat dari an-Nasai dari Abu Mas'ud yang melarang seseorang mengimami orang lain dalam wilayah kekuasaannya. Di sisi lain, juga tedapat adanya riwayat yang meyebutkan bahwa yang berhak mengimami jenazah adalah wali / pemimpin. Hal ini sebagaimna yang dilakukan oleh Hasan ra (cucu Nabi SAW) menyuruh Sa'id bin al'Ash yang merupakan gubernur Madinah saat itu untuk mengimami shalat jenazah atas jenazah saudaranya Husain r.a.. kedua riwayat ini sepertinya bertentangan satu sama lain. Terlepas dari permasalahan di atas, fenomena yang terjadi hari ini ketika hendak mengimami shalat jenazah adalah selalu mendahulukan keluarga mayat tanpa memperhatikan kefasihan membaca al-Quran.

Selain itu, Rasul SAW. juga pernah tidak menshalatkan jenazah pelaku maksiat tertentu tanpa udzur padahal beliau sedang di tempat. Tetapi beliau hanya menyuruh para shahabat untuk menshalatkan jenazah tersebut.
Di antara jenazah yang tidak Beliau shalatkan itu adalah jenazah pelaku zina dan jenazah pelaku ghulul. Perbuatan ghulul di zaman Rasul SAW. telah bertransformasi menjadi korupsi di zaman ini. Sedangkan pelakunya di sebut dengan koruptor. Adanya wacana untuk tidak menshalatkan jenazah koruptor baik itu di DPR RI maupun di tingkat akademisi yang diwakili oleh tokoh-tokoh ormas islam sepertinya terinspirasi dari hadis yang menyatakan Rasul tidak menshalatkan pelaku ghulul.

Dari penjelasan di atas, yang menjadi pokok permasalahan dalam penulisan jurnal ini adalah bagaimana kehujjahan dan pemahaman hadis tentang shalat jenazah yang lebih terfokus kepada hadis-hadis tentang siapa orang yang berhak mengimami shalat jenazah dan Rasul tidak menshalatkan jenazah pelaku maksiat seperti pelaku zina dan koruptor.

\section{PEMBAHASAN}

1. Hadis yang menjelaskan tentang orang yang berhak mengimami shalat jenazah

a) Hadis tentang penguasa lebih diutamakan menjadi imam shalat jenazah

Potongan hadis yang menjelaskan bahwa penguasa lebih di utamakan menjadi imam shalat jenazah penulis temukan dalam kitab Ahkaam al-Janaaiz wa Bid'uha yang ditulis oleh Syaikh Muhammad Nashiruddin alAlbani. ${ }^{1}$ Untuk memastikan apakah hadis ini terdapat dalam kutub tis'ah, maka penulis mencari

1 Muhammad Nashiruddin al-Albani, Ahkaam al-Janaaiz, wa Bidh'uha, (Beirut: Maktabah al-Islamiy, 1986 M/1406 H), cet. 4, j. 1, h. 100 
informasi yang terdapat dalam kitab Mu'jam al-Mufahras li Alfaazh alHadiits al-Nabawi, namun penulis tidak menemukan ada potongan hadis seperti hadis yang dimaksud. Oleh karena itu penulis melanjutkan mencari informasi hadis tersebut ke dalam kitab Mausuu'ah al-Athraaf al-Hadits an-Nabawi al-Syarif namun hasilnya penulis juga tidak menemukan hadis tersebut.

Oleh karena informasi tentang hadis tersebut juga tidak ditemukan dalam kitab Mausuu'ah al-Athraaf al-Hadiits an-Nabawi al-Syariif, maka penulis mencoba menelusurinya dengan menggunakan maktabah syamilah dan penulis menemukan bahwa hadis tersebut terdapat dalam:

1) kitab al-Mushannaf karya Abdul Razaq pada kitab alJanaaiz, bab Man Ahaqqu bi ash-Shalati 'ala al-Mayyit, juz 3, halaman 471, no. 6369

2) kitab as-Sunan al-Kubra li alBaihaqi karya oleh Imam Baihaqi pada kitab al-Janaaiz, bab Man Qaala al-Waliy Ahaqqu bi Ash-Shalah 'Ala alMayyit, hadis no. 7143 dan 7144. ${ }^{2}$

3) Kitab al-Mu'jam al-Kabir karya Ath-Thabrani pada juz 3, hal. 136, no. Hadis 2912 . $^{3}$

${ }^{2}$ Ahmad bin Husain bin 'Ali bin Musa al-Khusraujurdi al-Khurrasani Abu Bakar alBaihaqi (selanjutnya disebut dengan alBaihaqi), as-Sunan al-Kubra li al-Baihaqi, (Beirut: Dar Kutub al-'Ilmiyah, 2003 M / 1424 H), cet. 3, j. 4, h. , no. 6

${ }^{3}$ Sulaiman bin Ahmad bin Ayyub alQasim ath-Thabrani (selanjutnya disebut dengan ath-Thabrani), al-Mu'jam al-Kabiir, (Mosul: Maktabah al-'Ulum wa al-Hukm, 1404 H/1983 M), cet. 2, j. 3, h. 136, hadis no. 2912
Adapun hadis tersebut adalah:

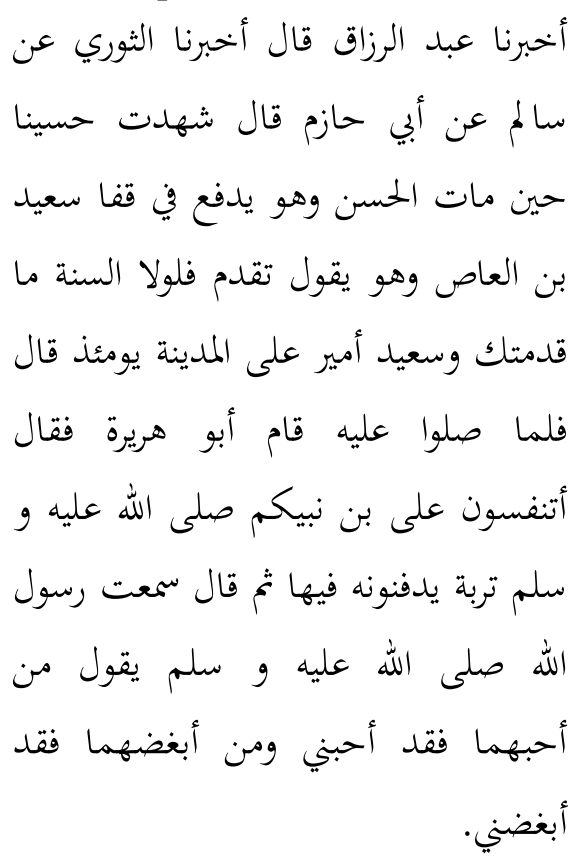

Artinya: telah menceritakan kepada kami Abdurrazzaq, ia berkata telah menceritakan kepada kami atsTsauri dari Salim dari Abu Hazim, ia berkata: aku menyaksikan Husain ketika Hasan meninggal, saat itu ia menepuk bahu Said bin al-'Ash sambil berkata "majulah, seandainya bukan karena sunnah tentu aku tidak akan menyuruhmu maju”. Dan ketika itu Said merupakan gubernur Madinah. Ketika mereka telah selesai melaksanakan shalat, berdirilah Abu Hurairah dan berkata "akan kah kalian melumuri cucu Nabi kalian dengan tanah yang kalian gunakan untuk menguburkannya? Padahal aku pernah mendengar Rasulullah SAW. bersabda Barang

${ }^{4}$ Abu Bakar Abdurrazzaq bin Hammam ash-Shan'ani (selanjutnya disebut dengan Abdul Razzaq), Mushannaf Abdurrazzaq, Tahqiq: Habiburrahman al-A'zhami, (Beirut: Maktabah al-Islami, $1403 \mathrm{H}$ ), cet. 3, j. 3, h. 471, no. 6369 
siapa yang mencintai keduanya berarti ia mencintai aku, namun barang siapa yang membenci keduanya berarti ia membenci aku. (H.R. Abdul Razzaq)

Hadis di atas juga diriwayatkan secara makna oleh imam Baihaqi dalam Sunan alKubra dan Thabrani dalam Mu'jam al-Kabir. ${ }^{5}$ Hadis tersebut disampaikan oleh tabi'in, dan tidaklah marfu' kepada Rasulullah SAW..

b) Hadis tentang larangan mengimami orang lain di wilayah kekuasaan orang yang diimami

Untuk memastikan apakah hadis ini terdapat dalam kutub tis'ah, maka penulis mencari informasi yang terdapat dalam kitab Mu'jam al-Mufahras li Alfaazh alHadiits al-Nabawi, dengan menggunakan kata yaummu dan sulthanihi maka diperoleh informasi bahwa hadis-hadis tersebut terdapat di dalam: ${ }^{6}$

1) kitab al-Jaami' ash-Shahih karya Imam Muslim pada kitab Masaajid wa Mawaadhi'u ashShalah, bab Man Ahaqqu bi alImaamah hadis nomor 290 dan $291 .^{7}$

\footnotetext{
5 al-Baihaqi, op.cit., cet. 3, j. 4, h. , no. 6 , ath-Thabrani, op.cit., cet. 2 , j. 3, h. 136, hadis no. 2912

${ }^{6}$ A.J. Weinsnk. Mu jam al-Mufahras Li Alfaazh al-Hadiits al-Nabawi, (Leiden: E.J. Brill L, 1965 M), j. 1, h. 8 dan j. 2, h. 503

7 Al-Imam al-Hafidz Abu al-Husain Muslim bin Hajjaj al-Qusyairi an-Naisaburi (selanjutnya disebut Imam Muslim), Shahih Muslim, (Riyadh: Dar Thayyibah li an-Nasyri wa at-Tauzi', 1427 H / 2006 M) j. 1, h. 302, no. 290 dan 291, kitab Masaajid wa Mawaadhi'u ash-Shalah, bab Man Ahaqqu bi al-Imaamah
}

2) Kitab al-Jaami' ash-Shahih (Sunan at-Tirmidzi) karya imam at-Tirmidzi pada Kitab Shalat, bab Maa Jaa a Man Ahaqqu bil Imaamah hadis nomor 60 dan kitab adab hadis no $24 .^{8}$

3) Sunan Abu Dawud karya Imam Abu Dawud pada kitab shalat bab no 60 (bab man ahaqu bi alImaamah). ${ }^{9}$

4) Kitab Sunan an-Nasa'i karangan Imam an-Nasai pada kitab alImaamah bab no 6 (bab Ijtimaa' al-Qaumi wa fiihim al-Wali). ${ }^{10}$

5) Kitab Sunan Ibnu Majah karya Ibnu Majah pada kitab Iqaamatu ash-Shalat wa Sunnatu Fiihaa, bab Man Ahaqqu bl alImaamah. ${ }^{11}$

Secara lengkap, hadis tersebut adalah sebagai berikut:

8 Abu Isa Muhammad bin Isa bin Tsaurah bin Musa bin Dhahhaq al Salamiy alTirmudzi (Selanjutnya disebut dengan Imam At-Tirmidzi), Sunan at-Tirmidzi, (Beirut: Dar Ihya at-Turats al-'Arabi, 1398 H/1978 M), tahqiq: Ahmad Muhammad Syakir Dkk, cet. 2, j. 1, h. 458, Kitab Shalat, bab Maa Jaa a Man Ahaqqu bil Imaamah

${ }^{9}$ Abu Dawud Sulaiman bin Asy-'asy asSijistani al-Azdi (selanjutnya disebut Abu Dawud), Sunan Abu Dawud, (Beirut: Dar Ibnu Hazm, 1418 H / 1997 M), cet. 1, j. 1, h. 277, hadis no. 582, kitab ash-Shalat, bab man ahaqu no al-Imaamah

${ }^{10}$ Abu Abdur Rahman Ahmad bin Syua'ib an-Nasa'i (selanjutnya disebut dengan Imam an-Nasai), Sunan an-Nasai bi Syarhi asSuyuthi wa Haasyiyatu as-Sanadi, (Beirut: Dar al-Ma'rifah, 1420 H), cet. 5, j. 2, h 410, kitab al-Imaamah

${ }^{11}$ Abu Abdillah Muhammad bin Yazid al-Qazwaini (selanjutnya disebut Ibnu Majah), Sunan Ibnu Majah, (Damaskus: Dar ar-Risalah al-'Alamiyyah, 1430 H/2009 M), tahqiq: Syeikh Syuaib Arnouth, cet. 1, j. 2, h. 121, no hadis 980, kitab Iqaamatu ash-Shalatu wa Sunnatu fiihaa, bab man ahaqqu bil al imaamah 


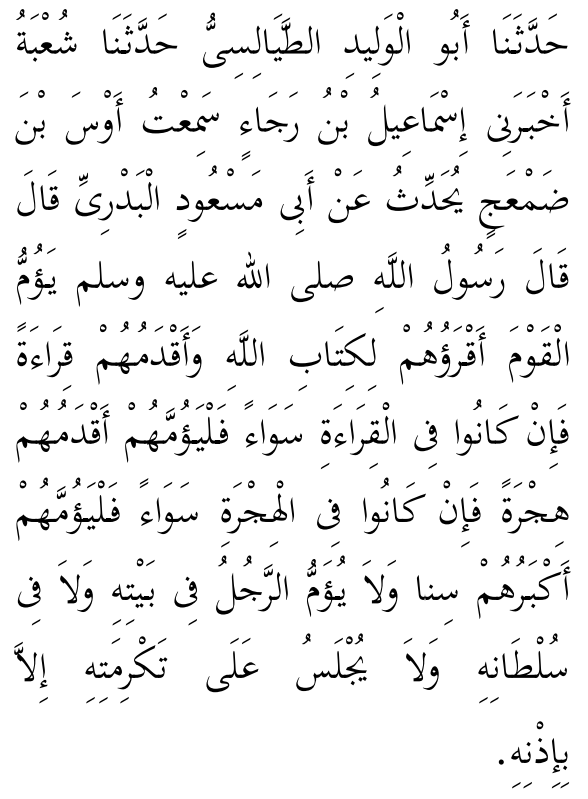

Artinya: telah menceritakan kepada kami abu Walid ath-Thayalisi, ia berkata telah menceritakan kepada kami Syu'bah, ia berkata telah menceritakan kepadaku Isma'il bin Raja', ia berkata aku telah mendengar Aus bin Dham'aj bercerita tentang Abu Mas'ud alBadri, ia berkata Rasulullah Saw. telah bersabda "yang berhak mengimami suatu kaum adalah orang yang paling baik membaca al-Qurannya,dan hendaklah mereka mendahulukan membaca al-Quran itu, jika bacaan al-Quran mereka sama, maka hendaklah yang mengimami mereka yang terlebih dahulu hijrah. Jika dalam hal hijrah mereka sama, maka hendaklah yang mengimami mereka orang yang lebih tua dari mereka. janganlah seseorang di antara kamu mengimami orang lain di rumahnya dan juga di dalam wilayah kekuasaannya, dan

12 Abu Dawud, op.cit., Sunan Abu Dawud, cet. 1, j. 1, h. 277, hadis no. 582, kitab ash-Shalat, bab man ahaqu no al-Imaamah janganlah dia duduk di rumah orang lain itu pada kursi kehormatannya kecuali dengan izinnya. (H.R. Abu Dawud)

Hadis tersebut juga diriwayatkan oleh Muslim, Tirmidzi, Nasai, Ibnu Majah.

\section{Hadis tentang Rasul tidak menshalatkan jenazah pelaku zina}

$$
\begin{aligned}
& \text { حدثنا بذلك الحسن بن علي حدثنا عبد } \\
& \text { الرزاق انبأنا هعمر عن الزهري عن أبي } \\
& \text { سلمة بن عبد الرحمن عن جابر بن عبد } \\
& \text { الله: أن رجلا من أسلم جاء إلى النبي } \\
& \text { صلى الله عليه و سلم فاعترف بالزنا } \\
& \text { فأعرض عنه ثم اعترف فاعرض عنه حتى } \\
& \text { شهد على نفسه أربع شهادات فقال النبي } \\
& \text { صلى الله عليه و سلم إبك جنون؟ قال لا } \\
& \text { قال أحصنت؟ قال نعم فأمر به فرجم } \\
& \text { بالمصلى فلما أذلقته الحجارة فر فأدرك } \\
& \text { فرجم حتى مات فقال رسول الله صلى الله } \\
& \text { عليه و سلم خيرا ولم يصل عليه.ب }
\end{aligned}
$$

Artinya: telah menceritakan kepada kami Hasan bin 'Ali ia berkata, telah menceritakan kepada kami Abdul Razaq, ia berkata telah memberitakan kepada kami Ma'mar dari az-Zuhri dari Abi Salamah bin Abdul Rahman dari Jabir bin Abdillah bahwasanya seorang laki-laki dari Suku Aslam datang menemui Rasulullah SAW. mengakui dirinya telah berzina,

${ }^{13}$ At-Tirmidzi, op.cit., j. 4, h. 36, hadis no. 1429, kitab al-Hudud, Bab Maa Jaa a Fii Dar u al-Haddu 'Ani al-Mu'tarifi Idza Raja'a 
namun beliau SAW. berpaling darinya. Laki-laki itu kembali mengakuinya dan beliau berpaling darinya. Sehingga laki-laki itumengaku sampai empat kali. Akhirnya Rasul SAW. bertanya kepadanya: "apakah kamu gila"? ia menjawab "tidak". Beliau bertanya lagi "apakah kamu sudah menikah”? laki-laki itu menjawab "ya”. Rasul SAW menyuruh untuk merajamnya, ia pun dirajam ditempat yang lapang (mushalla). Maka ketika ia merasakan sakit kena lemparan batu, ia kabur, lalu ditangkap dan dirajam lagi sampai meninggal. Nabi Shallallahu 'alaihi wasallam bersabda "ia dalam kebaikan" dan beliau tidak menshalatkannya. (H.R. atTirmidzi)

Hadis di atas juga diriwayatkan oleh an-Nasai dalam Sunnannya pada kitab al-Janaaiz, bab Tarku Ash-Shalah 'Ala AlMarjum hadis no. 1956. Al-Bukhari juga meriwayatkan hadis yang sama namun pada akhir hadisnya beliau menyebutkan fashalla 'alaihi.

Selain dari hal itu, hadis yang semakna dengan hadis riwayat at-Tirmidzi di atas juga diriwayatkan oleh Abu Dawud dalam Sunannya kitab al-Janaaiz, bab Ash-Shaatu 'Ala Man Qatalathu Al-Hudud, hadis no. 3188. Imam al-Baihaqi juga meriwayatkan dalam Sunannya pada kitab Jummaa'u Abwaabi AsySyahiidi wa Man Yushalli 'Alaihi wa Yughassil, Bab ash-Shalatu 'Ala Man Qatalathu Hudud, hadis no. 6831.

\section{Hadis tentang Rasul tidak menshalatkan jenazah koruptor}

$$
\begin{aligned}
& \text { حدثنا محمد بن رمح أنبأنا الليث بن سعد } \\
& \text { عن يهيى بن سعيد عن محمد ابن يهيى بن } \\
& \text { حبان عن ابن عمرة عن زيد بن خالد } \\
& \text { الجهني قال توين رجل من أشجع بخيبر. } \\
& \text { فقال النبي صلى الله عليه و سلم: صلوا } \\
& \text { على صاحبكم، فأنكر الناس ذلك وتغيرت } \\
& \text { له وجوههم فلما رأى ذلك قال إن } \\
& \text { صاحبكم غل في سبيل الله قال زيد } \\
& \text { فالتمسوا في متاعه فإذا خرزات من خرز } \\
& \text { يهود ما تساوى درهمين. ؟ }
\end{aligned}
$$

Artinya: Telah menceritakan kepada kami Muhammad bin Ramh, ia berkata telah menceritakan kepada kami al-Laits bin Sa'id dari Yahya bin Sa'id dari Muhammad bin Yahya bin Hibban dari Ibnu 'Amrah, dari Zaid bin Khalid al-Juhani ia berkata telah meninggal seorang laki-laki pada perang khaibar, maka Nabi SAW. bersabda :Shalatlah kalian atas saudara kalian!”. Maka orangorang ketika itu mengingkari perintah Rasul itu, dan wajah mereka berubah kepada Rasul SAW. ketika rasul melihat hal itu beliau bersabda "sesungguhnya saudara kalian telah melakukan kecurangan di jalan Allah. Zaid berkata merekapun memeriksa barang bawaannya ternyata dia mengambil manik-manik milik

14 Ibnu Majah, op.cit., Sunan Ibnu Majah, , j. 2, h. 950, kitab al-Jihad, bab alGhulul, hadis no, 2848 
orang yahudi yang nilainya kurang dari dua dirham. (H.R Ibnu Majah)

Hadis di atas juga diriwayatkan oleh Abu Dawud dalam sunannya pada kitab jihad, bab fii ta'zhiimi al-ghulul, hadis no. 2712. An-Nasai dalam sunannya pada kitab al-janaaiz, bab ashshalatu 'ala man ghalla, hadis no. 1959 dan Imam Ahmad bin Hanbal dalam musnadnya hadis no. 17031.

\section{Pemahaman Hadis tentang Orang yang Berhak Mengimami Shalat Jenazah}

Dalam hal ini, penulis menemukan ada dua riwayat yang menjelaskan tentang siapa yang lebih berhak untuk menjadi imam shalat jenazah. Hadis tersebut adalah:

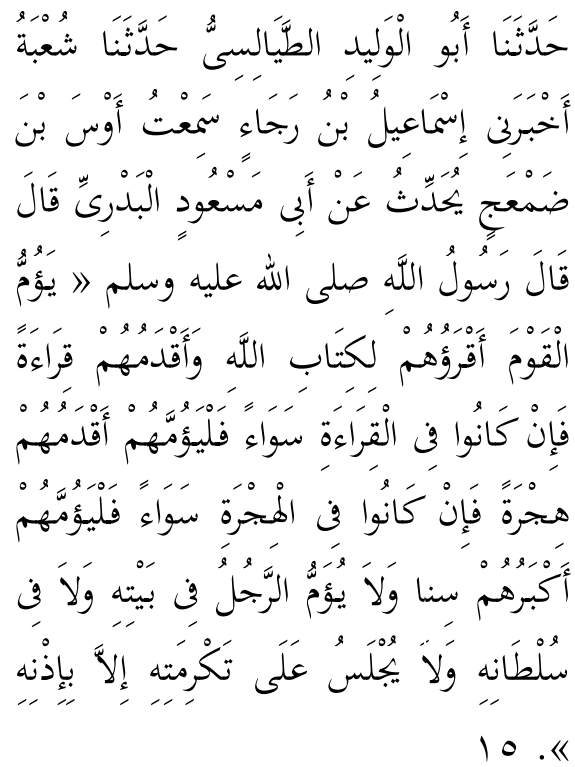

Artinya: telah menceritakan kepada kami abu Walid ath-Thayalisi, ia berkata telah menceritakan kepada

15 Hadis ini juga diriwayatkan dengan lafadz Abu Dawud dan diriwayatkan secara makna oleh Imam Muslim, at-Tirmidzi, anNasai, dan Ibnu Majah. Lihat hal 5 kami Syu'bah, ia berkata telah menceritakan kepadaku Isma'il bin Raja', ia berkata aku telah mendengar Aus bin Dham'aj bercerita tentang Abu Mas'ud alBadri, ia berkata Rasulullah SAW. telah bersabda "yang berhak mengimami suatu kaum adalah orang yang paling baik membaca al-Qurannya,dan hendaklah mereka mendahulukan membaca al-Quran itu, jika bacaan al-Quran mereka sama, maka hendaklah yang mengimami mereka yang terlebih dahulu hijrah. Jika dalam hal hijrah mereka sama, maka hendaklah yang mengimami mereka orang yang lebih tua dari mereka. janganlah seseorang diantara kamu mengimami orang lain dalam wilayah kekuasaannya, dan janganlah dia duduk di rumah orang lain itu pada kursi kehormatannya kecuali dengan izinnya. (H.R. Abu Dawud)

Hadis di atas, menerangkan bagaimana kriteria orang yang pantas untuk memimpin shalat secara umum. Setelah itu, Rasul melanjutkan sabdanya dengan melarang umatnya mengimami orang lain dalam wilayah kekuasaan orang tersebut dan juga melarang umatnya untuk duduk ditempat duduk kehormatan orang lain. ini menunjukkan betapa Rasul mengajarkan ketinggian adab yang harus diperhatikan oleh setiap muslim.

Para ulama berbeda pendapat dalam memahami makna lafaz уаитти al-qauma aqrauhum likitabillah. Sebagian ulama mengatakan bahwa yang dimaksud dengan lafaz yaummu al-qauma aqrauhum likitabillah adalah orang 
yang lebih baik pemahamannya tentang agama, namun ada juga pendapat yang memahami sebagaimana zhahir hadis. ${ }^{16}$

Menyikapi perbedaan ini, anNawawi mengatakan bahwa orang yang lebih dalam pemahaman agamanya sangat diutamakan untuk menjadi imam dari pada orang yang lebih baik bacaannya, karena bacaan shalat telah ditentukan, sementara pemahaman fikih tidak demikian. Kadangkala di dalam shalat terjadi hal-hal yang yang solusinya dapat diketahui oleh seseorang yang paham akan hukum Islam. Oleh karena itu, Rasulullah SAW. lebih mendahulukan Abu Bakar menjadi Imam karena Abu Bakar lebih mengetahui sunnah dari pada sahabat yang lain karena beliau selalu bersama Rasulullah SAW, sementara itu ada sahabat yang lain yang lebih fasih bacaannya daripada Abu Bakar. ${ }^{17}$

Selanjutnya Nabi SAW. mendahulukan orang yang bagus bacaannya karena mereka (para sahabat r.a) beriman setelah mereka dewasa, maka mereka telah paham sebelum mereka membaca, sehingga tidak seorangpun di antara mereka yang qari kecuali mereka telah paham dengan apa yang mereka baca. Adapun generasi sesudahnya mereka belajar alQuran sejak kecil sebelum mereka paham. Oleh karenanya setiap faqih

${ }^{16}$ Ahmad bin 'Ali bin Hajar Abu Fadhl al-'Asqalani asy-Syafi'i (selanjutnya disebut Ibnu Hajar al-'Asqalani), Fathul Baari Syarah shahih al-Bukhari (selanjutnya disebut Fathul Baari), (Beirut: Dar al-Ma'rifah, 1379 H), j. 2, h. 171

${ }^{17}$ Ibnu Hajar al-'Asqalani, ibid., j. 2, h. di zaman shahabat merupakan qari, tetapi pada zaman setelah shahabat setiap qari belum tentu faqih. ${ }^{18}$

Adapun pernyataan Nabi walaa yaummu arrajulu fii baitihi walaa fii sulthanihi walaa yajlisu 'ala takrimatihi illa bi idznihi menunjukkan bahwa shahibul manzil (pemilik rumah) lebih diutamakan dalam mengimami shalat di rumahnya karena ia merupakan penguasa di rumahnya, adapun seorang tamu atau si pendatang dilarang untuk menjadi imam atas tuan rumah kecuali jika tuan rumah mengizinkannya. Hal ini sesuai dengan hadis:

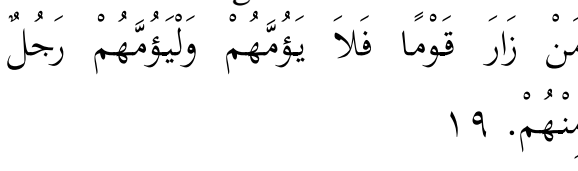

Artinya: Barang siapa yang mengunjungi suatu kaum maka janganlah mengimami mereka, dan hendaklah yang mengimami mereka laki laki dari kaum tersebut. (H.R. Abu Dawud)

Hadis walaa yaummu arrajulu fii baitihi walaa fii sulthanihi walaa yajlisu 'ala takrimatihi illa bi idznihi mengisyaratkan bahwa pemilik sesuatu merupakan penguasa terhadap apa yang dimilikinya. sementara itu, imam (pemimpin) tertinggi adalah penguasa terhadap apa yang dimilikinya. Oleh karena itu, Ibnu Umar shalat dibelakang al-Hajjaj (seorang penguasa dimasa itu), bahkan, di dalam riwayat yang

18 Husain bin Mas'ud al-Baghawi (selanjutnya disebut dengan al-Baghawi), Syarhu as-Sunnah lil Imam al-Baghawi, (Beirut: Maktabah al-Islami, 1403 H / 1983 M), cet. 2 , j. 3, h. 396

${ }^{19}$ Abu Dawud, op.cit, j. 1, h. 232, bab Imaamati az-Zair, hadis no. 596 
shahih dari Ibnu Umar disebutkan bahwa seorang imam masjid harus didahulukan atas seseorang yang bukan penguasa. $^{20}$

Zain Ibnu al-Munayyar mengatakan apabila imam a'zham (pemimpin, kalifah, presiden, gubernur, suthan, bupati atau walikota dalam suatu wilayah) mengunjungi suatu tempat dalam wilayah kekuasaannya, maka pemilik tempat tersebut tidak boleh maju menjadi imam. Tetapi seharusnya ia mempersilahkan kepada pemimpin tertinggi agar terkumpul dua hak yaitu hak sebagai imam untuk memimpin shalat, dan hak sebagai pemilik, dimana orang lain dilarang melakukan tindakan apapun di tempat yang menjadi miliknya kecuali atas izinnya. $^{21}$

Lebih lanjut asy-Syafi'i menjelaskan bahwa apabila wali negeri atau sulthan masuk ke suatu negeri yang berada di bawah pemerintahannya, lalu berkumpul wali negeri itu bersama orang lain pada wilayah tersebut, maka wali negeri tersebut lebih berhak menjadi imam. Tidaklah seseorang yang tampil ke depan mendahului yang berkuasa dalam kekuasaannya baik dalam shalat fardhu atau shalat sunnat atau shalat hari raya. ${ }^{22}$

${ }^{20}$ Muhammad bin Abdul Rahman bin Abdul Rahim al-Mubarakfuri abu al-'ala (selanjutnya disebut al-Mubarakfuri), Tuhfatul Ahwadzi bi Syarhi Jamai at-Tirmidzi, (Beirut: Dar Kutub al-'Ilmiyyah, tt), j. 2, h. 29

${ }^{21}$ Ibnu Hajar al-'Asqalani, op.cit., Fathul Baari, j. 2, h. 172.

${ }^{22}$ Muhammad bin Idris asy-Syafi'i, Abu Abdillah (selanjutnya disebut dengan AsySyafi'i), al-Umm, (Beirut: Dar Ma'rifah , 1393 H), j. 1, h. 157
Selanjutnya beliau menambahkan tidak boleh bagi penguasa dan yang punya rumah untuk menjadi imam jika ia tidak fasih membaca al-Quran. Kalau ia menjadi imam juga, maka shalatnya sempurna, dan shalat orang yang dibelakangnya menjadi rusak jika ada orang yang fasih membaca alQuran menjadi makmumnya. Oleh karena itu, apabila sultan, atau wali negeri, atau tuan rumah menunjuk orang lain untuk menjadi imam, maka orang itu telah diberikan kewenangan untuk menjadi imam dan diikuti dalam shalatnya. Karena pada saat itu ia telah mewakili sulthan. ${ }^{23}$

Dengan demikian dapat dipahami orang yang paling berhak menjadi imam adalah penguasa yang bagus bacaannya (fasih) dan faqih, jika bacaannya tidak fasih dan ia tidak faqih, maka ia lebih diutamakan untuk menunjuk seseorang yang fasih bacaan alQurannya dan faqih untuk menjadi imam di tempat dilaksanakannya shalat jama'ah. Selain itu, seseorang dilarang merebut hak imam dari penguasa kecuali penguasa tersebut telah memberikan izin atasnya. Begitu juga halnya dengan imamnya orang yang punya rumah, ia harus fasih bacaan al-Qurannya dan faqih. Jika kedua syarat tersebut tidak terpenuhi maka ia lebih diutamakan mempersilahkan orang yang lebih fasih dan faqih untuk menjadi imam.

Begitulah Islam mengajarkan bagaimana seseorang harus menghormati pemimpinnya tidak

${ }^{23}$ Asy-Syafi' i, Ibid., h. 157 
hanya dalam masalah kehidupan bernegara tetapi juga dalam masalah ketaatan kepada Allah. Tidak hanya di dalam shalat berjamaah biasa, namun juga pada shalat jenazah yang dilakukan secara berjamaah. Meskipun shalat jenazah bacaan shalatnya dibaca secara sir, namun hal itu tetap menuntut kefasihan lidah dalam membaca bacaan shalatnya karena boleh jadi salah dam pengucapan huruf akan menimbulkan kesalahan pada maksud dari bacaan yang dibaca. Oleh karenanya di dalam shalat jenazah disunnahkan untuk mendahulukan pemimpin yang bagus bacaannya untuk menjadi imam sebagaimana yang dilakukan oleh Husain ketika Hasan meninggal dan ia meminta Sa'id bin al-'Ash (gubernur Madinah waktu itu) untuk memimpin shalat jenazah Hasan. Beliau mengatakan "majulah, seandainya bukan karena sunnah tentu aku tidak akan menyuruhmu maju".

$$
\begin{aligned}
& \text { أخبرنا عبد الرزاق قال أخبرنا الثوري عن } \\
& \text { سالم عن أبي حازم قال شهدت حسينا } \\
& \text { حين مات الحسن وهو يدفع في قفا سعيد } \\
& \text { بن العاص وهو يقول تقدم فلولا السنة ما } \\
& \text { قدمتك وسعيد أمير على المدينة يومئذ قال } \\
& \text { فلما صلوا عليه قام أبو هريرة فقال } \\
& \text { أتنفسون على بن نبيكم صلى الله عليه و } \\
& \text { سلم تربة يدفنونه فيها ثم قال سمعت رسول } \\
& \text { الله صلى الله عليه و سلم يقول من }
\end{aligned}
$$

$$
\begin{aligned}
& \text { أحبهما فقد أحبني ومن أبغضهما فقد } \\
& \text { أبغضني. }
\end{aligned}
$$

Artinya: telah menceritakan kepada kami Abdurrazzaq, ia berkata telah menceritakan kepada kami atsTsauri dari Salim dari Abu Hazm, ia berkata: aku menyaksikan Husain ketika Hasan meninggal, saat itu ia menepuk bahu Said bin al-'Ash sambil berkata "majulah, seandainya bukan karena sunnah tentu aku tidak akan menyuruhmu maju”. Dan ketika itu Said merupakan gubernur Madinah. Ketika mereka telah selesai melaksanakan shalat, berdirilah Abu Hurairah dan berkata "akan kah kalian akan melumuri cucu Nabi kalian dengan tanah yang kalian gunakan untuk menguburkannya? Padahal aku pernah mendengar Rasulullah SAW. bersabda Barang siapa yang mencintai keduanya berarti ia mencintai aku, namun barang siapa yang membenci keduanya berarti ia membenci aku. (H.R. Abdul Razzaq)

Ibnu Mundzir berkata:

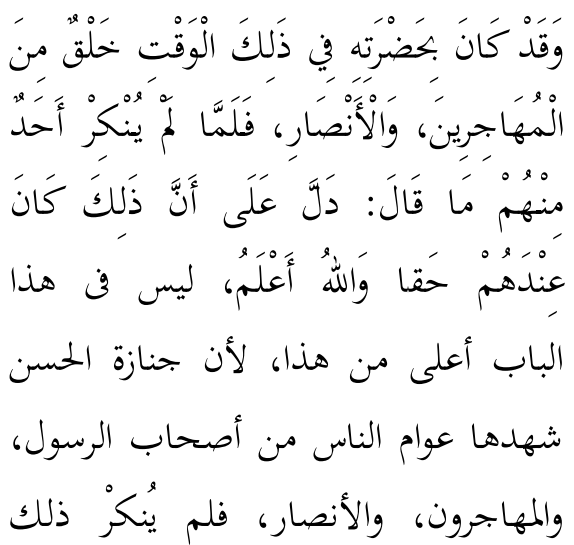

${ }^{24}$ Hadis ini juga diriwayatkan oleh Abdul Razzaq, al-Baihaqi dan ath-Thabrani. Lihat hal. 3-4 


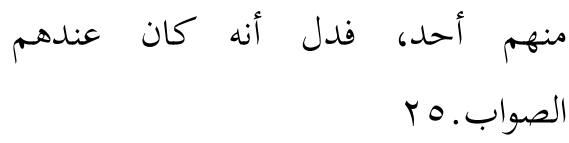

Artinya: sungguh pada waktu itu, jenazahnya dihadiri oleh kaum muhajirin dan anshar. Pada waktu itu tidak seorangpun dari mereka yang mengingkarinya. Ini menunjukkan bahwa hal itu adalah benar. tidaklah pada bab ini pembahasan yang lebih tinggi dari pada itu. karena jenazah Hasan dihadiri orang banyak dari muhajirin dan Anshar. Dan tidak ada seorang pun dari mereka yang mengingkarinya. Itu menunjukkan bahwasanya perbuatan tersebut benar menurut mereka.

Perkataan Husain ra. kepada Sa'id bin al-'Ash ra. "taqaddam, falau laa sunnatu, maa qaddamtuka" sebagaimana riwayat di atas merupakan ungkapan seorang sahabat yang sangat mengetahui tentang sunnah Rasul SAW.. Beliau (Husain) rela memberikan hak mengimami jenazah saudaranya (Hasan) kepada Said bin al-'Ash yang merupakan gubernur Madinah saat itu.

Riwayat dari Ibnu Hazm di atas menunjukkan bahwa apabila penguasa hadir dalam penyelenggaraan shalat jenazah maka ia lebih diutamakan untuk mengimaminya sebagaimana shalat jumat dan shalat dua hari raya. ${ }^{26}$

${ }^{25}$ Ibnu Baththal, op.cit., cet. 3, j. 3, h. 308. Abu Bakar Muhammad bin Ibrahim bin Mundzir an-Naisaburi (selanjutnya disebut Ibnu Mundzir), al-Ausath fii as-Sunani wa alIjmaa'i wa al-Iktilafi, (Riyadh: Dar athThayyibah, 1405 H/ 1985 M), cet. 1, j. 5, h. 399

${ }^{26}$ Khalaf bin Sulaiman bin Sa'ad bin Ayyub al-Qadhi Abu Walid al-Tujaybi al-
Ulama menambahkan menurut Ibnul Qasim yang dimaksud dengan wali di atas adalah pemimpin, qadhi, atau jendral. Adapun menurut al-Mutharraf dan Ibnu Majisyun pemimpin yang dimaksud adalah pemimpin tertinggi yang memiliki kekuasaan penuh atau wewenang khusus bukan semua pemimpin atau hakim, sedangkan menurut Ibnu Wahab yang dimaksudkan di sini adalah hakim. $^{27}$ Namun jika ia berhalangan maka digantikan oleh pemimpin negeri itu atau Qadhi, namun jika juga tidak hadir barulah penghulu jika mereka juga tidak hadir maka baru yang mengimami itu dari pihak keluarga seperti ayah, paman, anak dan cucu dan seterusnya menurut ashabah waris. $^{28}$

Dalam menentukan siapa yang berhak mengimami shalat jenazah, tentunya tidak boleh menyelisihi ketentuan umum yang telah disebutkan dalam hadis riwayat Abu Dawud, Muslim, at-Tirmidzi dan an-Nasai di atas, artinya, seorang pemimpin atau penguasa harus didahulukan menjadi imam jika ia memiliki syarat jadi imam secara umum yaitu qari dan faqih sehingga mampu untuk memimpin shalat tersebut. Dalam hal ini, berdasarkan dari kisah Hasan yang menyuruh Said bin al-'Ash sebagai imam dalam shalat jenazah atas

Andalusi al-Qurthubi al-Baji at-Tamimi adzDzahabi al-Maliki (selanjutnya disebut dengan al-Baji), al-Muntaqa Syarh al-Muwatha, j. 2, h. 40

${ }^{27}$ Ibid., j. 2, h. 40

28 Manshur bin Yunus bin Idris alBahwati, kasysyaf al-Qana' 'an Matani alIqna', (Beirut: Dar al-Fikr, 1402 H), j. 2, h. 110 
Husain, dapat di ambil kesimpulan bahwa Hasan meyakini bahwa Said bin al-'Ash yang ketika itu merupakan gubernur Madinah, merupakan seorang yang bagus bacaan al-Qurannya (qari) dan juga ia merupakan seorang yang faqih yang mengerti dan paham akan pelaksanaan shalat jenazah.

Selain itu, pada hadis riwayat Abdul Razaq di atas tidak ditemukan adanya indikasi yang menyatakan bahwa Hasan berwasiat tentang siapa yang akan mengimami shalat jenazahnya. Hal ini dimaksudkan bahwa wasiat merupakan hutang orang yang tinggal yang harus ditunaikan termasuk permintaan siapa yang akan mengimami shalat jenazah.

Dalam riwayat lain disebutkan dari Dhahhak sebagaimana berikut:

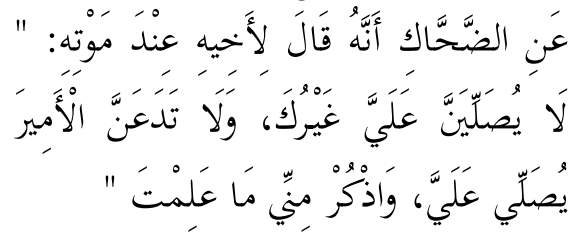

Artinya: dari Dhahhak ia berkata kepada saudaranya sebelum meninggal janganlah mereka shalat atasku selain dari engkau, dan jangan meminta penguasa untuk mensahalatkanku, ingatlah dariku apa yang kamu ketahui.

Riwayat tersebut menjelaskan bahwa seseorang boleh berwasiat tentang siapa yang akan menjadi imam ketika dia meninggal, sehingga orang yang diberi wasiat untuk menshalatkan jenazah lebih diutamakan dari penguasa. Hal ini menunjukkan bahwa gugurnya hak penguasa untuk mengimami shalat jenazah rakyatnya jika si mayat mewasiatkan orang yang akan mengimaminya.

Persoalan mewasiatkan ini, telah berlaku sejak zaman Abu Bakar ash-Shiddiq ra. yang Berwasiat agar Umar bin Khatab menshalatkannya, Umar berwasiat agar Shuhaib menshalatkannya, Ummu Salamah berwasiat agar yang menshalatkannya Said bin Zaid, Abu Bakrah berwasiat agar yang menshalatkannya Abu Barzah, 'Aisyah berwasiat yang menshalatkannya Abu Hurairah, Ibnu Mas'ud berwasiat agar yang menshalatkannya Zubair. ${ }^{29}$

Dalam riwayat lain juga disebutkan bahwa Abu Sarihah berwasiat untuk menshalatkannya Zaid bin Arqam, Amru bin Harits gubernur Kuffah datang untuk menshalatkannya. Maka anaknya berkata "wahai gubernur, sesungguhnya bapakku berwasiat agar yang menshalatkannya adalah Zaid bin Arqam. Maka majulah Zaid untuk mengimami Abu Sarihah. ${ }^{30}$ Dari kisah tersebut, dapat dipahami bahwa penguasa akan terhapus haknya untuk mengimami shalat jenazah rakyatnya jika rakyatnya itu berwasiat siapa yang akan mengimami shalat jenazahnya.

Dari penjelasan di atas dapat disimpulkan bahwa orang yang didahulukan untuk menjadi imam dalam shalat jenazah adalah orang yang diberi wasiat untuk

29 Syamsuddin Abu Abdullah Muhammad bin Abdullah az-Zarkasyi alMishri al-Hanbali (selanjutnya disebut azZarkasyi), Syarh Azzarkasyi 'Ala Mukhtashar al-Kharqi, (Beirut: Dar Kutub al-'Ilmiyah, 1423 H/2002 M), j. 1, h. 319

${ }^{30}$ Ibid., j.1, h. 319 
mengimami shalat jenazah, jika si mayat tidak pernah berwasiat sebelumnya maka pemimpin lebih diutamakan untuk menjadi imam dari pada keluarga mayat jika pemimpin tersebut bagus bacaan alQurannya dan seorang yang faqih, dan jika pemimpin tidak hadir maka barulah pihak keluarga si mayat seseuai dengan urutan ashabah dalam harta warisan atau wali nikah, tetapi harus dengan ketentuan bagus bacaan alQurannya dan faqih sehingga ia mampu mendirikan shalat jenazah tersebut.

Problem di tengah masyarakat hari ini adalah banyak dari pemimpin yang kurang paham dan fasih dalam membaca al-Quran begitu juga dengan keluarga mayat, banyak di antara mereka yang ditunjuk menjadi imam tidak fasih dalam membaca kitab Allah, padahal di antara yang menjadi jamaahnya ada yang fasih bacaannya dan faqih sehingga dia layak menjadi imam. Maka dalam kondisi ini sangat dituntut kearifan dan kesadaran dari pemimpin akan kemampuannya dalam membaca kitab Allah, dengan demikian ia boleh menunjuk seorang yang lebih fasih untuk mengimami shalat jenazah. Begitu juga halnya dengan keluarga si mayat yang ditunjuk jadi imam jika tidak fasih dalam membaca al-Quran maka sangat dituntut kearifannya untuk mempersilahkan memimpin shalat jenazah kepada orang yang lebih fasih dan lebih faqih darinya.

\section{Pemahaman Hadis Tentang Rasul Tidak Menshalatkan Jenazah Pelaku Maksiat}

\section{a. Hadis tentang Rasul tidak menshalatkan jenazah pelaku zina}

Zina merupakan perbuatan keji yang disuruh Allah Swt. untuk menjauhinya. Islam sebagai agama rahmatan lil 'aalamiin sangat melindungi kesucian dan kehormatan umatnya. Oleh karena itu, Islam memberikan hukuman yang sangat berat jika ada umatnya yang berani melakukan zina. Hukuman zina tersebut biasa dikenal dengan istilah rajam. Hukuman rajam tersebut telah berlansung sejak zaman Rasulullah Saw., di mana seseorang yang berzina akan dimasukkan ke dalam lubang setinggi dada atau bahunya lalu dilemparilah orang tersebut sampai mati.

Hadis yang menerangkan kisah tentang rajam tersebut sangatlah banyak. Namun yang menjadi pembahasan di sini adalah hadis yang menyatakan bahwa Rasul Saw. tidak menshalatkan jenazah pelaku zina yang meninggal karena di hukum rajam. Di antara hadis tersebut adalah:

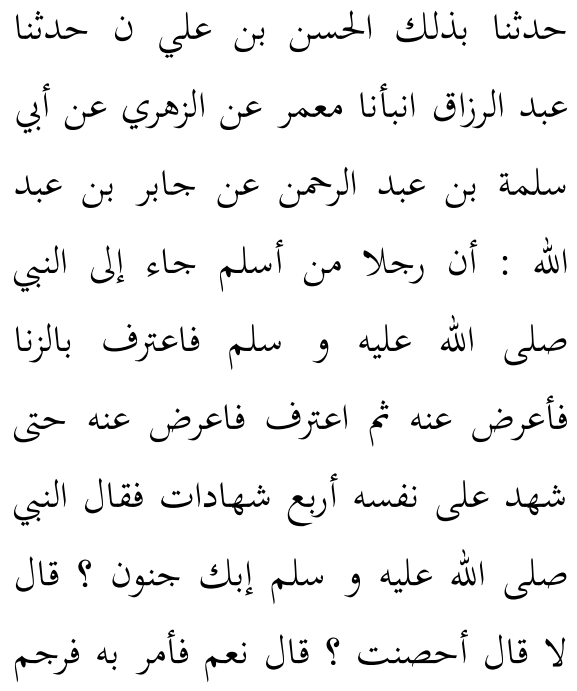




$$
\text { فرجم حتى فلى ملمات أذلقته الحجارة فر فأدرك }
$$

Artinya: telah menceritakan kepada kami Hasan bin 'Ali ia berkata, telah menceritakan kepada kami Abdul Razaq, ia berkata telah memberitakan kepada kami Ma'mar dari az-Zuhri dari Abi Salamah bin Abdul Rahman dari Jabir bin Abdillah bahwasanya seorang laki-laki dari Suku Aslam datang menemui Rasulullah Saw. mengakui dirinya telah berzina, namun beliau Saw. berpaling darinya. Laki-laki itu kembali mengakuinya dan beliau berpaling darinya. Sehingga laki-laki itumengaku sampai empat kali. Akhirnya Rasul Saw. bertanya kepadanya: "apakah kamu gila"? ia menjawab "tidak". Beliau bertanya lagi "apakah kamu sudah menikah”? laki-laki itu menjawab "ya". Rasul Saw menyuruh untuk merajamnya, ia pun dirajam ditempat yang lapang (mushalla). Maka ketika ia merasakan sakit kena lemparan batu, ia kabur, lalu ditangkap dan dirajam lagi sampai meninggal. Nabi Saw. bersabda "ia dalam kebaikan" dan beliau tidak menshalatkannya. (H.R. atTirmidzi)

Hadis di atas juga diriwayatkan oleh an-Nasai dalam Sunan-nya pada kitab al-janaaiz, bab tarku ash-shalah 'ala almarjum hadis no. 1956. Al-Bukhari juga meriwayatkan hadis yang sama

31 At-Tirmidzi, op.cit., Sunan atTirmidzi, j. 4, h. 36, hadis no. 1429, kitab alHudud, Bab Maa Jaa a Fii Dar u al-Haddu 'Ani al-Mu'tarifi Idza Raja'a namun pada akhir hadisnya beliau menyebutkan fashalla 'alaihi.

Selain dari hal itu, hadis yang semakna dengan hadis riwayat at-Tirmidzi di atas juga diriwayatkan oleh Abu Dawud dalam kitab kitab al-Janaaiz, bab ash-Shalaatu 'Ala Man Qatalathu al-Hudud, hadis no. 3188. Imam Baihaqi juga meriwayatkan dalam Sunan-nya pada kitab Jummaa'u Abwaabi Asy-Syahiidi wa Man Yushalli 'Alaihi wa Yughassil, Bab ash-Shalatu 'Ala Man Qatalathu Hudud, hadis no. 6831.

Dalam hadis riwayat atTirmidzi di atas, disebutkan bahwa Rasul Saw. tidak menshalatkan jenazah Maiz bin Malik dari suku Aslam yang telah dirajam. Secara zhahir, hadis ini menyatakan bahwa jenazah pelaku zina tidak dishalatkan oleh Rasul Saw. namun Beliau menyuruh para shahabat untuk menshalatkannya. Hadis ini tampak bertentangan dengan hadis riwayat imam Bukhari bahwasanya Rasulullah Saw menshalatkan jenazah Maiz bin Malik.

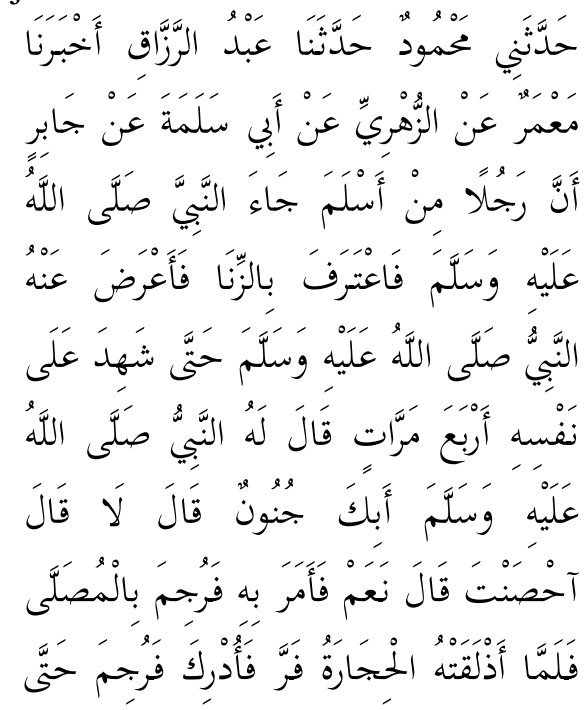




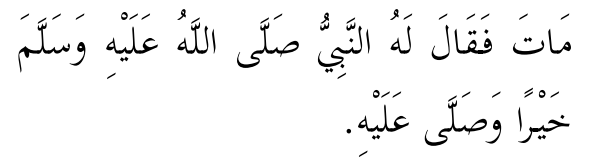

Artinya: telah menceritakan kepadaku Mahmud bin Ghailan, ia berkata telah menceritakan kepadaku Abdul Razaq, ia berkata telah menceritakan kepadaku Ma'mar dari az-Zuhri dari Abu Salamah dari Jabir bin Abdillah bahwasanya seorang laki-laki dari Suku Aslam datang menemui Rasulullah Saw. mengakui dirinya telah berzina, namun beliau Saw. berpaling darinya. Laki-laki itu kembali mengakuinya dan beliau berpaling darinya. Sehingga lakilaki itumengaku sampai empat kali. Akhirnya Rasul Saw. bertanya kepadanya: "apakah kamu gila"? ia menjawab "tidak". Beliau bertanya lagi "apakah kamu sudah menikah"? laki-laki itu menjawab "ya". Rasul Saw menyuruh untuk merajamnya, ia pun dirajam ditempat yang lapang (mushalla). Maka ketika ia merasakan sakit kena lemparan batu, ia kabur, lalu ditangkap dan dirajam lagi sampai meninggal. Nabi Shallallahu 'alaihi wasallam bersabda "ia dalam kebaikan" dan beliau menshalatkannya.(H.R. Bukhari)

Kedua hadis di atas, memiliki persamaan dan perbedaan. Adapun persamaannya adalah hadis tersebut berasal dari Abdul Razaq dari Ma'mar dari Az-Zuhri dari Abi Salamah dari Jabir bin Abdillah.

${ }^{32}$ Abu Abdillah Muhammad bin Ismail bin Ibrahim bin Mughirah al-Ja'fi al Bukhari (selanjutnya disebut dengan Imam Bukhari), al-Jaami' as-Shahih, (Beirut: Dar Kutub al'Ilmiyah, 1996 M/1417 H), kitab al-Hudud, bab ar-Rajmu bi al-Mushalla, cet. 1, j. 8, h. 166 , hadis no. 6820
Sedangkan perbedaannya adalah pada hadis riwayat Tirmidzi, anNasai, Abu Dawud, dan Baihaqi menjelaskan bahwa jenazah Maiz bin Malik tidak dishalatkan, sedangkan pada riwayat Bukhari menjelaskan bahwa jenazah Maiz bin Malik dishalatkan Rasulullah.

Selain dari hadis riwayat alBukhari di atas, hadis yang menyatakan Rasul tidak menshalatkan jenazah pelaku zina juga tampak bertentangan dengan hadis yang diriwayatkan imam Muslim dari 'Imran bin Hushain bahwasanya Rasul menshalatkan jenazah seorang wanita Juhainah yang mengaku berzina.

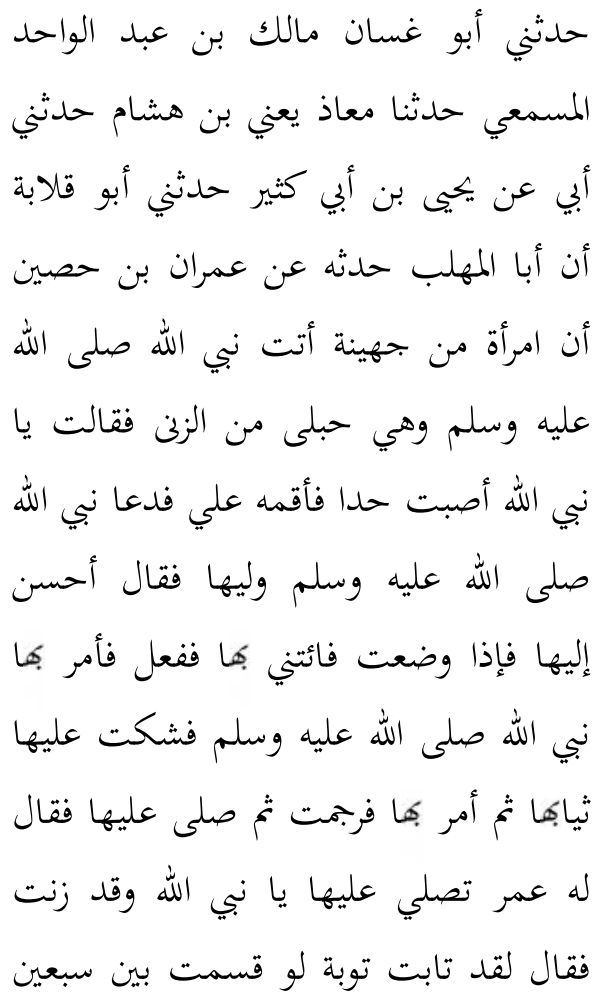




$$
\text { من أهل المدينة لوسعتهم وهل وجدت من أن جادت بنفسها لله تعالى. }
$$

Artinya: telah menceritakan kepada kami Abu Ghassan Malik bin Abdul Wahid al-Musma'i, ia berkata telah menceritakan kepada kami Mu'adz. bin Hisyam ia berkata telah menceritakan kepadaku bapakku (Hisyam) dari Yahya bin Abu Katsir ia berkata telah menceritakan kepadaku Abu Qilabah bahwasanya Abu Mihlab telah menceritakan kepadanya dari 'Imran bin Hushain bahwasanya seseorang wanita Juhainah datang menemui Nabi Saw. dan dia sedang mengandung anak dari hasil zina. Wahai Rasulullah, aku telah melakukan perbuatan yang mengaharuskan hukuman hadd. Karena itu berlakukanlah hukuman had itu kepadaku. Kemudian Rasul memenggil wali perempuan tersebut dan bersabda "perlakukanlah dia dengan baik! Jika dia melahirkan, bawalah dia menghadap kepadaku”. Maka wali wanita itu mengerjakannya. Setelah dia melahirkan, Nabi menyuruh pakaian wanita itu dikencangkan lalu memerinahkan supaya wanita itu dirajam dan kemudian beliau menshalatkannya. Maka umar lalu bertanya kepada beliau Saw. Wahai Nabiyullah, engkau menshalatkan jenazahnya padahal ia telah melakukan zina. Rasul menjawab "sesungguhnya dia benar benar telah bertaubat, apabila taubatnya dibagikan kepada tujuh puluh orang penduduk Madinah niscaya

\footnotetext{
${ }^{33}$ Imam Muslim, op.cit., Shahih Muslim, kitab al-hudud, bab man i'tarafa 'ala nafsihi bi az-zina j. 3, h. 1324, hadis no. 1649
}

akan mencukupi mereka semua. Apakah kamu pernah mendapati taubat yang lebih baik daripada kerelaannya untuk mengorbankan nyawanya karena Allah Swt?. (H.R. Muslim)

Berdasarkan hadis riwayat imam Muslim di atas, dapat di pahami bahwa Rasul Saw. menshalatkan jenazah pezina.

\section{Penyelesaian Pertentangan Hadis}

Hadis Riwayat at-Tirmidzi dari jalur Hasan bin 'Ali yang mengatakan bahwa Rasul tidak menshalatkan jenazah pelaku zina dengan hadis riwayat al-Bukhari dari jalur Mahmud bin Ghailan yang menyatakan bahwa Rasul menshalatkan jenazah pelaku zina jika di pahami secara zhahir, maka ke dua hadis tersebut seolah-olah bertentangan padahal keduanya diriwayatkan oleh Abdul Razaq dari Ma'mar. Adapun hadis yang diriwayatkan oleh al-Bukhari dari jalur Mahmud bin Ghailan dari Abdul Razaq menyelisihi hadishadis yang diriwayatkan oleh para hafidz yang menyatakan tidak dishalatkan atas Ma'iz. Oleh karena itu, untuk menghilangkan pertentangan tersebut akan digunakan metode al-jam'u wa attaufiq yaitu menggabungkan dua dalil tersebut dengan titik temu antara keduanya.

al-Mundziri dalam alHasysyiyah menjelasakan bahwa hadis yang mengatakan Rasul tidak menshalatkan jenzah pelaku zina diriwayatkan oleh delapan orang perawi dari Abdul Razaq, dan mereka tidak menyebutkan pernyataan washalla 'alaihi. Ibnu Hajar al-'Asqalani menjelaskan 
setelah menyebutkan seluruh riwayat tersebut berkata jumlah mereka yang menerima hadis dari Abdul Razaq tersebut lebih dari sepuluh orang. Di antara mereka ada yang mendiamkan akan tambahan tersebut dan sebagian yang lain menjelaskan tambahan riwayat tersebut. ${ }^{34}$ Adapun tambahan yang dimaksud adalah pernyataan washalla atau fashalla 'alaihi. ${ }^{35}$

Akan tetapi, menurut al'Asqalani imam Bukhari menganggap hadis riwayat Mahmud bin Ghailan lebih kuat dari riwayat delapan orang hafidz dengan adanya syawahid. ${ }^{36}$ Adapun syawahid yang dimaksud adalah hadis yang juga diriwayatkan oleh Abdul Razaq dalam kitab Sunan Abi Qurrah dari Abi Umamah bin Sahal bin Hanif tentang kisah Maiz bin Malik, sebagaimana berikut:

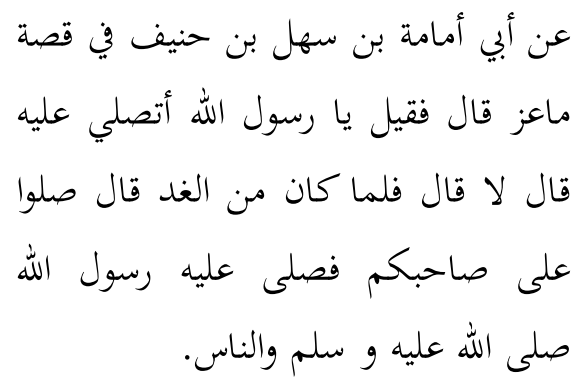

Artinya: dari Abu Umamah bin Sahal bin Hanif pada kisah Maiz dia berkata "wahai Rasulullah

34 Al-'Asqalani, op.cit., Fathul Baari, kitab al-Hudud, bab ar-Rajmu bi al-Mushalla, j. 12 , h. 130

35 Badruddin al-'Aini, op.cit., Syarh Sunan Abi Dawud, kitab al-Janaaiz, bab ashshalah 'alaa man qatalathu al-hudud, j. 6, h. 122

${ }^{36}$ Al-'Asqalani, op.cit., Fathul Baari, kitab al-Hudud, bab ar-Rajmu bi al-Mushalla, j. 12 , h. 130

${ }^{37}$ Al-'Asqalani, Ibid. h. 30 apakah engkau akan menshalatkannya”, Rasul menjawab tidak. Abu Umamah berkata ketika esok harinya Rasul berkata shalatlah kalian atas saudara kalian, maka Rasul menshalatkannya bersama para sahabat.

Riwayat ini memberikan solusi atas pertentangan yang terjadi antara hadis dari Mahmud bin Ghailan dengan hadis yang diriwayatkan oleh delapan orang yang hafidz yang mengatakan bahwa Rasul tidak menshalatkan jenazah orang pezina. Dalam riwayat tersebut disebutkan bahwa Rasul tidak menshalatkan jenazah Maiz pada hari kematiannya akan tetapi Beliau menshalatkan jenazah Maiz pada hari kedua setelah kematiannya dengan mengajak para sahabat untuk menshalatkannya. Dengan demikian dapat disimpulkan bahwa jenazah orang yang berzina tetap dishalatkan. Hal ini diperkuat dengan riwayat yang mengatakan bahwa Rasul Saw. menshalatkan jenazah wanita Juhainah yang berzina.

Dari penjelasan di atas, dapat kita simpulkan bahwa berdasarkan penjelasan dari hadis maka jenazah pelaku zina tetap dishalatkan oleh kaum muslimin, namun pemimpin, imam, atau tokoh masyarakat lebih disukai untuk tidak menshalatkannya disebabkan karena Rasul yang kala itu merupakan pemimpin, imam di kaumnya tidak menshalatkan jenazah pelaku zina sedangkan masyarakat lain wajib menshalatkannya.

Para ulama telah berbeda pendapat dalam masalah ini. Imam 
Malik mengatakan Imam memerintahkan untuk merajamnya dan menjauhkan dari keluarganya yang menshalatkan dan memandikannya dan imam tidak menshalatkannya untuk mencegah pelaku maksiat jika melakukan hal yang sama mereka tahu bahwa mereka termasuk orang yang tidak dishalatkan agar mereka menjauhi perbuatan yang sama. sebagian Malikiyah membolehkan Imam untuk menshalatkannya. Dari pendapat Malikiyyah diketahui bahwa dimakruhkan bagi Imam dan pemuka masyarakat shalat atas orang yang dirajam. Ini sesuai dengan pendapat Ahmad. Pendapat asy-Syafi'i shalat Imam tersebut tidak dimakruhkan. Pendapat azZuhri tidak ada shalat atas orang yang di rajam dan juga atas orang yang bunuh diri.

\section{b. Rasul tidak menshalatkan jenazah pelaku ghulul (koruptor)}

Hadis yang menunjukkan bahwa Rasul Saw. tidak menshalatkan orang yang belaku curang adalah:

$$
\begin{aligned}
& \text { حدثنا محمد بن رمح أنبأنا الليث بن سعد } \\
& \text { عن يجيى بن سعيد عن محمد ابن يهيى بن } \\
& \text { حبان عن ابن عمرة عن زيد بن خالد } \\
& \text { الجهني قال توفي رجل من أشجع بخيبر. } \\
& \text { فقال النبي صلى الله عليه و سلم: صلوا } \\
& \text { على صاحبكم، فأنكر الناس ذلك وتغيرت } \\
& \text { له وجوههم فلما رأى ذلك قال إن } \\
& \text { صاحبكم غل في سبيل الله قال زيد }
\end{aligned}
$$

$$
\begin{aligned}
& \text { فالتمسوا في متاعه فإذا خرزات من خرز } \\
& \text { يهود ما تساوى درهمين. }
\end{aligned}
$$

Artinya: Telah menceritakan kepada kami Muhammad bin Ramh, ia berkata telah menceritakan kepada kami al-Laits bin Sa'id dari Yahya bin Sa'id dari Muhammad bin Yahya bin Hibban dari Ibnu 'Amrah, dari Zaid bin Khalid alJuhani ia berkata telah meninggal seorang laki-laki pada perang khaibar, maka Nabi Saw. bersabda :Shalatlah kalian atas saudara kalian!'. Maka orang-orang ketika itu mengingkari perintah Rasul itu, dan wajah mereka berubah kepada Rasul Saw. ketika rasul melihat hal itu beliau bersabda "sesungguhnya saudara kalian telah melakukan kecurangan di jalan Allah. Zaid berkata merekapun memeriksa barang bawaannya ternyata dia mengambil manik-manik milik orang yahudi yang nilainya kurang dari dua dirham. (H.R Ibnu Majah)

Hadis di atas juga diriwayatkan oleh Abu Dawud dalam sunannya pada kitab jihad, bab fii ta'zhiimi al-Ghullul, hadis no. 2712. An-Nasai dalam sunannya pada kitab al-janaaiz, bab Ash-shalatu 'ala man Ghalla, hadis no. 1959 dan Imam Ahmad bin Hanbal dalam musnadnya hadis no. 17031.

Permasalahan ghulul merupakan permasalahan yang sangat urgent di sisi Allah Swt., dan bukan permasalahan yang mudah, oleh karenanya perbuatan ghulul memiliki ancaman yang sangat berat. Permasalahan ghulul pada

${ }^{38}$ Imam Ibnu Majah, op.cit., j. 2, h. 950, kitab al-Jihad, bab al-Ghulul, hadis no, 2848 
asalnya terjadi pada ghanimah (harta rampasan perang) yang diambil secara tidak benar. Perbuatan tersebut merupakan pengkhianatan.39

Permasalahan ghulul juga merupakan permasalahan yang menyangkut kepentingan kaum muslimin. Oleh karena itu, Nabi Saw. menolak untuk menshalatkan jenazah pelaku ghulul sebagai peringatan buat generasi sesudahnya. Hal itu tidak menggugurkan kewajiban shalat atas kaum muslimin yang lain, mereka wajib untuk menshalatkannya.40

Dalam bahasa Arab arti dari kata ghalla, yaghullu, ghallan, wa ghullan,wa ghuluulan yang secara harfiah berarti akhadza al-syai a fii khfyatin wa dassahu fii matha'thi, yaitu mengambil sesuatu secara sembunyi-sembunyi dan memasukkan ke dalam hartanya. ${ }^{41}$ Pendapat lain mengatakan bahwa arti dari ghalla, yaghullu, ghallan, ghuluulan adalah al-khiyaanatu fii maghnami khashshatan yaitu berkhianat dalam harta rampasan perang. ${ }^{42}$ Dalam kontek kekinian, makna ghulul lebih tepat diartikan kepada korupsi karena korupsi

\footnotetext{
${ }^{39}$ Abdul Muhsin al-'Ibad, Syarh sunan Abu Dawud, j. 14, h. 311

40 Muhammad bin Shaleh bin Muhammad al-'Utsaimin, asy-Syarhul Mumta' 'Ala Zaadul Mustaqni', (Mesir: Dar Ibnul Jauzi, 1422 H), cet. 1, j. 5, h. 350

41 Muhammad bin Mukarram bin Manzhur al-Afriqi al-Mishri (selnjutnya disebut dengan Ibnu Manzhur), Lisaanul 'Arabi, (Beirut: Dar al-Shadr, tt), cet. 1, j. 11, h. 499

42 Ibid., h. 499. Lihat juga: Ahmad Warson Munawwir, Kamus Arab - Indonesia, (Yogyakarta: al-Munawwir, 1984), h. 1089
}

adalah suatu tindakan mengambil atau menyalah gunakan kebijakan untuk memperkaya diri sendiri.

Pernyataan Rasul Saw. "shalluu 'alaa shahibikum", menunjukkan bahwa Rasul Saw. tidak menshalatkan jenazah tersebut. Adapun sebab Rasul tidak menshalatkan jenazah tersebut adalah si mayat berbuat curang di jalan Allah. Sedangkan curang itu adalah khianat, karena mengambil haq orang lain pada harta ghanimah.

Pernyataan Rasul Saw. "shalluu 'alaa shaahibikum", juga menjadi dalil bahwasanya perbuatan dosa tidak mengeluarkan pelakunya dari iman. Karena jika pelaku ghulul merupakan orang kafir sebagaimana anggapan orang khawarij, maka Rasul tidak akan memerintahkan orang untuk shalat atasnya, karena jenazah orang kafir tidak boleh dishalatkan oleh orang muslim, ahl fadhl, dan lain-lain.43

Menurut Ibnu Abdil Bar maksud dari Rasul Saw. meninggalkan shalat dan menyuruh para sahabat menshalatkannya adalah beliau tidak menshalatkan orang yang terbukti melakukan dosa untuk mencegah manusia dari melakukan maksiat, dan melakukan dosa besar. Hal ini sebagaimana beliau tidak menshalatkan Maiz bin Malik yang mendapatkan hukuman had karena berzina, dan menyuruh sahabat menshalatkannya, begitu juga beliau tidak menshalatkan

43 Muhammad bin Ali bin Adam bin Musa al-Itsyubi al-Wallawi, Syarh Sunan anNasa'i al-Musamma Dzakhiratul 'Aqabi fii Syarhil Mujtaba, (Riyadh: Dar al-Mi'raj adDauliyah Lin Nasyr, 1424 H/2003M), cet. 1, j. 19, h. 252 
orang yang mati bunuh diri, hal itu dimaksudkan untuk mencegah orang setelah mereka. Pada dasarnya orang yang tidak menshalatkan itu adalah imam, dan imam dalam masalah agama adalah muhaddis, tetapi para imam tersebut tidak melarang orang lain untuk menshalatkannya melainkan menyuruh untuk menshalatkan.44

Pada zaman sekarang, perbuatan ghulul itu disebut dengan korupsi. Adapun pelakunya disebut dengan koruptor. Perbuatan korupsi tersebut telah menjadi ancaman serius dalam kehidupan berbangsa dan bernegara. Hal ini disebabkan karena perbuatan korupsi merupakan perbuatan melawan hukum dengan menyalahgunakan wewenang untuk memperkaya diri atau golongan dengan cara mengambil uang negara dengan cara sembunyi-sembunyi seperti money loundry (pencuacian uang) atau bisa berbentuk penyuapan. Sama dengan apa yang terjadi pada zaman Nabi Saw. seorang sahabat Rasul mengambil harta rampasan perang dengan sembunyi-sembunyi dengan memasukkannya ke dalam saku bajunya tanpa ada seorang sahabatpun yang mengetahuinya.

Salah satu ormas islam yang menganjurkan untuk tidak menshalatkan jenazah koruptor adalah Nahdhatul Ulama pada tahun 2013. Sikap ini merupakan bentuk komitmen NU dalam upaya pemberantasan korupsi dan sebagai bentuk dukungan NU terhadap KPK dalam pemberantasan korupsi. Anjuran NU ini kembali hangat ketika Ketua bidang hukum PBNU

${ }^{44}$ Ibid., j. 19, h. 252
Robikin Emhas mengatakan keputusan tersebut berdasarkan keputusan Musyawarah NU di Cirebon, Jawa Barat pada tahun 2013 lalu. "Keputusan musyawarah NU di tahun 2013 menegaskan koruptor tidak boleh atau sebaiknya tidak dishalati oleh pengurus NU. Jadi pengurus NU dilarang menshalatkan jenazah koruptor," ujar Robikin dalam jumpa pers di Gedung KPK, Jakarta, Selasa (11/7/2017).45

Adapun dalil yang menjadi rujukan oleh $\mathrm{PB}$ NU adalah hadis Rasulullah Saw. yang menceritakan tindakan Rasulullah Saw. yang tidak mau menshaIatkan jenazah salah seorang sahabat karena yang bersangkutan melakukan korupsi terhadap harta hasil pampasan perang. 46

Jika dibandingkan cara atau proses mendapatkan serta tujuan antara perbuatan ghulul pada zaman Rasul Saw. dengan korupsi pada sekarang ini, maka dapat dikatakan bahwa cara melakukan ghulul tersebut dilakukan dengan cara sembunyi-sembunyi dengan tujuan untuk memperkaya diri sendiri. Begitu juga halnya dengan korupsi, juga dilakukan dengan cara sembunyi-sembunyi dan untuk memperkaya diri. dengan demikian mengqiyaskan antara ghulul dengan korupsi sudah benar dan cocok dengan realita sekarang.

Jika di dalam hadis disebutkan bahwa nilai bejana atau perhiasan

45

republika.co.id/berita/nasional/hukum/17/07/11

/ di akses tgl 25 september 2017 jam 19.00 WIB

${ }^{46}$ Ibid., . Adapun untuk hadisnya lihat kembali hal. 196-197 
yang diselundupkan oleh salah seorang sahabat yang jenazahnya tidak dishalatkan Rasul Saw adalah kurang dari dua dirham, maka hal itu sangatlah tidak sebanding dengan jenazah koruptor yang mengambil uang negara ratusan juta bahkan milyaran rupiah untuk tidak dishalatkan jenazahnya.

Namun demikian, anjuran meninggalkan shalat atas koruptor ini bukan berarti tidak ada shalat atas jenazah para koruptor secara mutlak. Koruptor yang belum bertaubat dan tidak mengembalikan hasil korupsinya sampai meninggal dunia, berarti mati dalam keadaan membawa dosa besar. Meskipun dosa besar, namun tindak korupsi tidak menyebabkan pelakunya jadi kafir. Artinya, jenazahnya tetap disikapi sebagai jenazah muslim. Dia wajib dimandikan, dikafani, dishalatkan, dan dimakamkan di pemakaman kaum muslimin. 47

Syaikhul Islam Ibnu Taimiyah mengatakan "Masyarakat umum boleh menshalatkannya. Adapun para tokoh agama yang menjadi panutan, jika mereka meninggalkan shalat atas jenazah tersebut, sebagai teguran atas yang lain dan untuk mengikuti perbuatan Nabi Saw, maka itulah yang benar".48

Dari penjelasan di atas, dapat disimpulkan bahwa jenazah seorang muslim yang berlaku curang (koruptor) tetap dihukum

\footnotetext{
47 https://konsultasisyariah.com/25321jenazah-koruptor-tidak-dishalati.html. di akses pada senin, 25 september 2017 jam 19.00 WIB

48 Taqiyuddin Abu Abbas Ahmad bin Abdul Halim bin Taymiyah al-harani, Мајтии' al-Fataawa, (Kairo, Dar al-Wafa, 1426 H / 2005 M), cet. 3 , j. 24, h. 286
}

seperti jenazah orang muslim lainnya, dan ia tidak keluar dari Islam, ia tetap dishalatkan oleh kaum muslimin yang hidup, adapun imam, pemimpin, pemuka masyarakat dianjurkan untuk meninggalkan shalat atasnya, hal ini bertujuan supaya menjadi peringatan bagi yang hadir dalam penyelenggaraan jenazah.

\section{KESIMPULAN}

Berdasarkan penelitian yang
telah penulis lakukan dapat
disimpulkan:

1. Kualitas hadis-hadis yang membicarakan tentang siapa yang berhak untuk mengimami shalat jenazah berkualitas shahih serta bisa dijadikan hujjah, karena hadishadis tersebut telah memenuhi syarat-syarat hadis maqbul. Adapun urutan dari orang yang berhak menjadi imam dalam shalat jenazah adalah orang yang diberikan wasiat, selanjutnya pemimpin, kemudian keluarga atau kerabat mayat, dan hendaknya mereka itu orang yang qari dan faqih.

2. Kualitas hadis-hadis yang membicarakan tentang Rasul tidak menshalatkan jenazah pelaku maksiat berkualitas shahih serta bisa dijadikan hujjah, karena hadishadis tersebut telah memenuhi syarat-syarat hadis maqbul. Rasul tidak menshalatkan jenazah pelaku maksiat tetapi Beliau menyuruh para shahabat untuk menshalatkannya. Dengan demikian, jenazah pelaku maksiat tetap dishalatkan karena mereka tidak keluar dari Islam. Namun, dianjurkan untuk tidak menshalatkan jenazahnya oleh pemuka agama, pemimpin dan 
pemuka masyarakat, hal ini bertujuan untuk mencegah orang lain untuk melakukan perbuatan yang sama, bukan menghilangkan kewajiban shalat atas jenazah tersebut.

\section{DAFTAR PUSTAKA}

Al-Quran al-Karim

al-Albani, Muhammad Nashiruddin, 1986 M/1406 H, Ahkaam alJanaaiz wa Bidh'uha, Beirut: Maktabah al-Islamiy, cet. 4, j. 1

al-'Asqalani, Ahmad bin 'Ali bin Hajar Abu Fadhl asy-Syafi'i, 1379 H, Fathul Baari Syarah shahih alBukhari, Beirut: Dar al-Ma'rifah), j. 2

al-Baghawi, Husain bin Mas'ud, 1403 H / 1983 M, Syarhu as-Sunnah lil Imam al-Baghawi, Beirut: Maktabah al-Islami, cet. 2, j. 3

al-Bahwati, Manshur bin Yunus bin Idris, $1402 \mathrm{H}$, kasysyaf al-Qana' 'an Matani al-Iqna', Beirut: Dar al-Fikr, j. 2

al-Baihaqi, Ahmad bin Husain bin 'Ali bin Musa al-Khusraujurdi alKhurrasani Abu Bakar, 2003 M/1424 H, as-Sunan al-Kubra li al-Baihaqi, Beirut: Dar Kutub al'Ilmiyah, cet. 3, j. 4

al-Baji, Khalaf bin Sulaiman bin Sa'ad bin Ayyub al-Qadhi Abu Walid alTujaybi al-Andalusi al-Qurthubi at-Tamimi adz-Dzahabi al-Maliki, al-Muntaqa Syarh al-Muwatha, j. 2

al-Bukhari, Abu Abdillah Muhammad bin Ismail bin Ibrahim bin Mughirah al-Ja'fi, 1996 M/1417 H, al-Jaami' as-Shahih, Beirut: Dar Kutub al-'Ilmiyah, cet. 1, j. 8 https://konsultasisyariah.com/25321jenazah-koruptor-tidakdishalati.html. di akses pada senin, 25 september 2017 jam 19.00 WIB

Ibnu Manzhur, Muhammad bin Mukarram al-Afriqi al-Mishri, tt, Lisaanul 'Arabi, (Beirut: Dar alShadr, cet. 1, j. 11

al-Mubarakfuri, Muhammad bin Abdul Rahman bin Abdul Rahim abu al'ala, tt, Tuhfatul Ahwadzi bi Syarhi Jamai at-Tirmidzi, Beirut: Dar Kutub al-'Ilmiyyah, tt), j. 2

Munawwir, Ahmad Warson, 1984, Kamus Arab - Indonesia, Yogyakarta: al-Munawwir

Ibnu Mundzir, Abu Bakar Muhammad bin Ibrahim an-Naisaburi, $1405 \mathrm{H} /$ 1985 M, al-Ausath fii as-Sunani wa al-Ijmaa'i wa al-Iktilafi, Riyadh: Dar ath-Thayyibah, cet. 1, j. 5

an-Naisaburi, Al-Imam al-Hafidz Abu al-Husain Muslim bin Hajjaj alQusyairi, 1427 H / 2006 M, Shahih Muslim, Riyadh: Dar Thayyibah li an-Nasyri wa at-Tauzi', j. 1

an-Nasa'i, Abu Abdur Rahman Ahmad bin Syua'ib, 1420 H, Sunan anNasai bi Syarhi as-Suyuthi wa Haasyiyatu as-Sanadi, Beirut: Dar al-Ma'rifah, cet. 5, j. 2

al-Qazwaini, Abu Abdillah Muhammad bin Yazid, 1430 H/2009 M, Sunan Ibnu Majah, Damaskus: Dar arRisalah al-"Alamiyyah, tahqiq: Syeikh Syuaib Arnouth, cet. 1, j. 2

https://republika.co.id/berita/nasional/h ukum/17/07/11/ di akses tgl 25 september 2017 jam 19.00 WIB

ash-Shan'ani, Abu Bakar Abdurrazzaq bin Hammam, 1403 H, Mushannaf 
Abdurrazzaq, Tahqiq: Habiburrahman al-A'zhami, Beirut: Maktabah al-Islami, cet. 3, j. 3

as-Sijistani, Abu Dawud Sulaiman bin Asy-'asy al-Azdi, 1418 H / 1997 M, Sunan Abu Dawud, Beirut: Dar Ibnu Hazm, cet. 1, j. 1

asy-Syafi'i, Abu Abdillah Muhammad bin Idris, $1393 \mathrm{H}$, al-Umm, Beirut: Dar Ma'rifah, j. 1

Ibnu Taymiyah, Taqiyuddin Abu Abbas Ahmad bin Abdul Halim bin al-Harani, $1426 \mathrm{H} / 2005 \mathrm{M}$, Мајтии' al-Fataawa, Kairo, Dar al-Wafa, cet. 3, j. 24

ath-Thabrani ,Sulaiman bin Ahmad bin Ayyub al-Qasim, 1404 H/1983 M, al-Mu'jam al-Kabiir, Mosul: Maktabah al-'Ulum wa al-Hukm, cet. 2, j. 3

al-Tirmidzi, Abu Isa Muhammad bin Isa bin Tsaurah bin Musa bin Dhahhaq al-Salamiy, 1398 H/1978 M, Sunan at-Tirmidzi, Beirut: Dar
Ihya at-Turats al-'Arabi, tahqiq: Ahmad Muhammad Syakir Dkk, cet. 2, j. 1

al-'Utsaimin, Muhammad bin Shaleh bin Muhammad, $1422 \mathrm{H}$, asySyarhul Mumta' 'Ala Zaadul Mustaqni', Mesir: Dar Ibnul Jauzi, cet. 1, j. 5

al-Wallawi, Muhammad bin Ali bin Adam bin Musa al-Itsyubi, 1424 H/2003M, Syarh Sunan an-Nasa'i al-Musamma Dzakhiratul 'Aqabi fii Syarhil Mujtaba, Riyadh: Dar al-Mi'raj ad-Dauliyah Lin Nasyr, cet. 1, j. 19

Weinsnk, A.J., 1965 M, Mu`jam alMufahras Li Alfaazh al-Hadiits alNabawi, Leiden: E.J. Brill L., j.1 dan j. 2

az-Zarkasyi, Syamsuddin Abu Abdullah Muhammad bin Abdullah al-Mishri al-Hanbali, 1423 H/2002 M, Syarh Azzarkasyi 'Ala Mukhtashar al-Kharqi, Beirut: Dar Kutub al-'Ilmiyah, j. 1 
108 Jurnal Ulunnuha Vol.7 No.2/Desember 2018 